
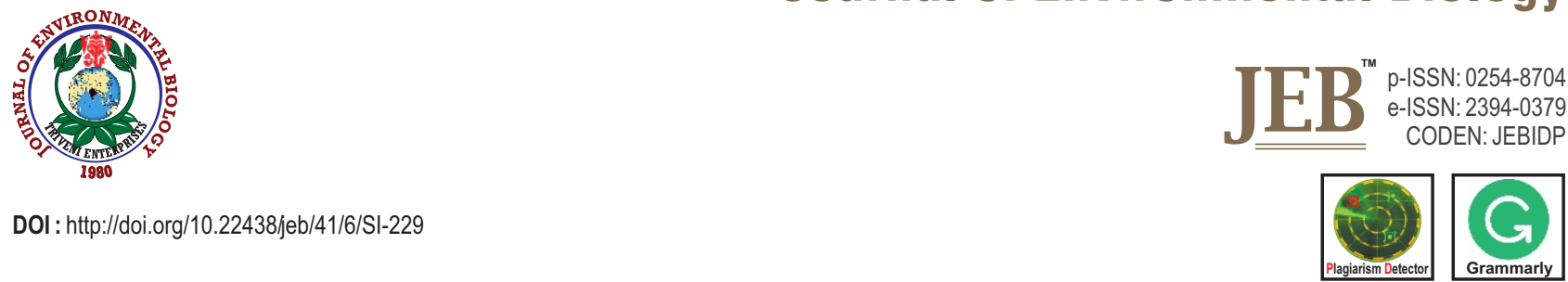

\title{
Diversity and density of Collembola as influenced by soil physico-chemical properties in fallow land ecosystem of Assam, India
}

\author{
S. Bhagawati ${ }^{1 *}$, B. Bhattacharyya ${ }^{1}$, B.K. Medhi' ${ }^{2}$, S. Bhattacharjee' and H. Mishra ${ }^{3}$ \\ ${ }^{1}$ Department of Entomology, Assam Agricultural University, Jorhat - 785013, India \\ ${ }^{2}$ Department of Soil Science, Assam Agricultural University, Jorhat-785 013, India \\ ${ }^{3}$ Krishi Vigyan Kendra, Assam Agricultural University, Karimganj-788712, India \\ *Corresponding Author Email : sudhansubhagawati@gmail.com
}

Revised received: 03.10 .2020

Accepted: 30.10 .2020

\section{Abstract}

Aim: To investigate the influence of soil physico-chemical properties on diversity and density of Collembola in an undisturbed fallow land ecosystem.

Methodology: Soil sampling was done at monthly intervals to explore the diversity, density and seasonal variation patterns of collembolan population in a fallow land ecosystem during March, 2015 to February, 2016. Collembolans were sampled using Tullgren funnel and identified by standard taxonomic keys. Finally, correlation studies were conducted to assess the influence of different soil physico-chemical properties on diversity and density of collembolans.

Results: Five species of Collembola (Cyphoderus sp., Entomobrya sp., Isotoma sp., Folsomia sp. and Hypogastrura sp.) belonging to 4 families (Cyphoderidae, Entomobryidae, Isotomidae and Hypogastruridae) were identified. Cyphoderus sp. was recorded to be the most abundant species contributing 44.29 percent of population. Analysis of different diversity indices revealed higher diversity of collembolans during summer, indicating the presence of relatively stable habitats as compared to other seasons. Summer season also recorded highest density of Collembola. During all the seasons studied, a strong significant positive correlation $(P<0.05$ and $P<0.01)$ of collembolan population was registered with soil moisture and organic carbon, respectively, however, remaining edaphic factors registered non-significant relationship with the collembolan density and diversity.

Interpretation: The study clearly indicated that the soil moisture and organic carbon content had a positive relationship with collembolan population and provides a relatively favourable ecological niche for their assemblages.

Key words: Collembola, Diversity, Ecosystem, Edaphic factors

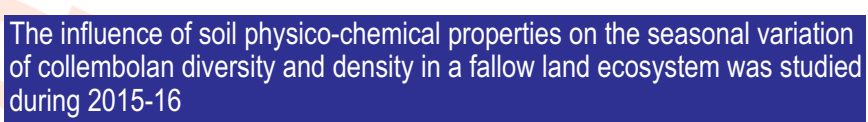
during 2015-16

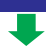

Monthly soil sampling were carried out and collembolans were extracted using funnel (TFM). Correlation studies were conducted between the different soil physico-chemical properties and both the diversity and density of collembolans.
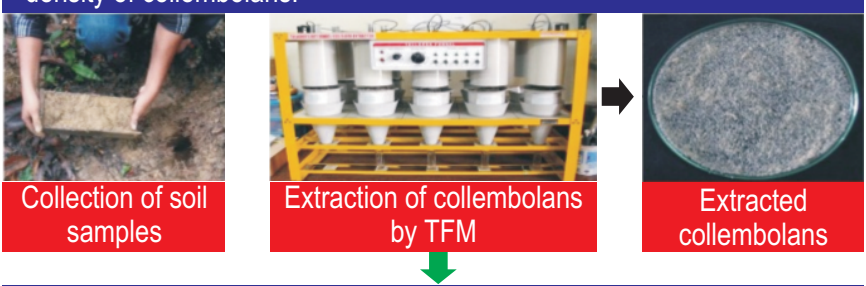

5 species of collembolans were identified of which Cyphoderus sp. was most dominant. Summer season recorded highest density and diversity of collembolan assemblages as compared to other season. $\checkmark$

Correlation studies revealed a significant positive correlation $(p<0.05$ and $p<0.01$ ) of collembolan density and diversity with soil moisture and organic carbon) during all the seasons. Other soil physicochemical properties like sand, silt, clay, soil microbial biomass carbon, pH and bulk density did not exhibited any distinct relationship with both the density and diversity of the collembolans.

How to cite : Bhagawati, S., B. Bhattacharyya, B.K. Medhi, S. Bhattacharjee and H. Mishra: Diversity and density of Collembola as influenced by soil physico-chemical properties in fallow land ecosystem of Assam, India. J. Environ. Biol., 41, 1626-1631 (2020). 


\section{Introduction}

Collembola, also known as springtails are small apterygote hexapods commonly occurring in large numbers in the surface and subsurface layers of the soil. Collembola is considered to be one of the most important groups of organisms due to their contribution towards soil genesis, dynamics and evolution. Collembola also acts as good bioindicator of soil health due to their quick response to the environmental changes, particularly towards anthropic modification (Stork and Eggleton, 1992; Van Straalen, 1997; Zeppelini et al., 2009). The world collembolan fauna is represented by 8,143 species belonging to 764 genera and 19 families whereas in India, a total of 301 species under 109 genera belonging to 19 families have been reported (Bhagawati et al., 2018). These groups of insects have immense potential to act as "Ecosystem service provider" as majority of the springtails feed on dead organic matter, decayed plant materials and many plant parasitic fungus and nematodes whereas some have been reported to increase the growth of mycorrhizae (Cassagnau, 1972; Hopkin, 1997; Larink, 1997).

Despite having immense potential as "Ecosystem service providers", the information on collembolan fauna of North East India is yet in infancy. Furthermore, being the "Biodiversity hotspot" and "Organic hub" of India, the collembolan diversity of this region cannot be overlooked. However, loss in the collembolan diversity due to the gradient of different land uses have already been well established (Cortet et al., 2002; Culik and Filho, 2003; Sousa et al., 2004; Sousa et al., 2006). Moreover, there are also reports in the reduction of collembolan diversity due to the presence of pollutants like pesticides and excessive nutrients as compared to natural ecosystem (Fiera, 2009). Changes in the collembolan community structure due to characterizing changes in the soil chemo-edaphic properties for various anthropogenic activities has also been well established (Filho et al., 2016). Hence, there is an urgent need to explore the undisturbed virgin soils, devoid of any agricultural interventions for proper documentation of collembolan fauna of this region.

Considering the above facts, the present study was undertaken to analyze the diversity density and seasonal variation of Collembola under undisturbed fallow land ecosystem of Assam (India) and also to study the influence of soil physicochemical properties on the collembolan population.

\section{Materials and Methods}

Study area description: Soil samplings were carried out at a fallow land ecosystems of Charaibahi village, Jorhat, Assam, India $\left(26^{\circ} 76^{\prime} \mathrm{N}\right.$ and $\left.94^{\circ} 19^{\prime} \mathrm{E}\right)$. The study sites are located in subtropical zone characterized by hot and humid summer (30$\left.35^{\circ} \mathrm{C}\right)$ followed by dry and cool winter $\left(10-15^{\circ} \mathrm{C}\right)$. The mean average rainfall is more than $2000 \mathrm{~mm}$ per annum with a high average humidity (approximately 85\%). Monsoon normally starts from June and continues up to September with pre-monsoon shower starting from mid-March. The intensity of rainfall decreases from October, reaching minimum during December / January. Soil moisture generally ranges from 16.1 to 24.31 per cent.

Collection of soil samples: Soil samples were collected from the aforementioned ecosystems in four seasons (spring, summer, autumn and winter) during March, 2015 to February, 2016. Rectangular soil sampler $(30 \mathrm{~cm} \times 11 \mathrm{~cm} \times 8 \mathrm{~cm})$ was used at a constant depth of $0-10 \mathrm{~cm}$ for collecting soil (Paul et al., 2011). Ten samples were collected per sampling during each season. Without disturbing the soil profile, the soil was taken out from the sampler and then soil samples were properly sealed, tagged and transported to the Laboratory of Soil Arthropod Pests, Department of Entomology, Assam Agricultural University, Jorhat for the extraction of Collembola.

Extraction of collembolans from collected soil samples: Collembolans were extracted with the help of Tullgren funnel by using Tungsten bulbs (40 Watt) kept at high light intensities exposed continuously up to $72 \mathrm{hrs}$ (Akoijam and Bhattacharyya, 2012). Soil microarthropods were collected in collection tubes containing ethyl alcohol and then transferred into a clean petridish for categorization of collembolans. The collembolans were then counted and profiled species wise under a Stereozoom Microscope (Model: Carl Zeiss Stemi 2000-C). Finally, the population density of collembolans was worked out (Singh et al., 1978).

Identification of collembolans: The preliminary basic characters of collembolans were examined under Stereozoom Microscope (Magnification: 5X and above) and identified by using standard taxonomic keys proposed by Santeshwari et al. (2013). The specimens were further confirmed by experts at the Department of Entomology and Agricultural Zoology, Institute of Agricultural Sciences, Banaras Hindu University, Varanasi, India. Relative abundance of different species of collembolans recorded from the fallow land ecosystem was also worked out and expressed in per cent.

Analysis of soil physico-chemical properties: Three soil samples were also collected in each season for the analysis of physico-chemical properties of soil. Mechanical analysis of the collected soil samples was done according to the international pipette method (Jackson, 1973). Moisture content of the samples was determined by following the standard AOAC (2000). Bulk density was determined from the soil cores (Chapman, 1965). Organic carbon was determined by dichromate oxidation method (Walkley and Black, 1934). Soil microbial biomass carbon was determined by fumigation extraction method (Vance et al., 1987)

Statistical analyses: Shannon-Weiner Index and Simpson Diversity were used to establish the diversity of Collembola in 
fallow land ecosystems by following the methodology of Clarke and Warwick (2001) and Simpson (1949), respectively. Evenness was calculated out by following the standard protocol of Leinster and Cobbold (2012). Simple correlation and regression was made between the population of collembola and different soil physico-chemical parameters to know the effect of different chemo-edaphic factors on collembolan population.

\section{Results and Discussion}

Seasonal soil samplings carried out at fallow land ecosystem recorded 5 collembola species (Cyphoderus sp., Entomobrya sp., Isotoma sp., Folsomia sp. and Hypogastrura sp.) under 4 different families (Cyphoderidae, Entomobryidae, Isotomidae and Hypogastruridae). Approximately, 1825 individuals of collembolans were collected during the sampling period which clearly reflects that the sampling sites were completely devoid of anthropogenic activities and maintained naturally by decomposition of crop residues and creating a favourable ecological niche for the edaphic fauna (Bartz et al., 2013). Among the 5 species, Cyphoderus sp. (44.29\%) was the most abundant followed by Isotoma sp. (24.29\%) and Entomobrya sp. (14.29\%) (Fig.1). Per cent abundance recorded in case of Hypogastrura sp. and Folsomia sp. was 10.00 and 7.14, respectively. Santeshwari et al. (2013) studied the collembolan fauna at diverse habitats of Varanasi, India and reported 13 genera under 8 families. Guru and Mohanty (1995) in a similar line of study reported Cyphoderus javanus (31.81\%) as the most abundant species followed by Isotoma sp. (24.60\%) and Hypogastrura sp. (15.65\%) at the top 5-10 cm layers of soil.

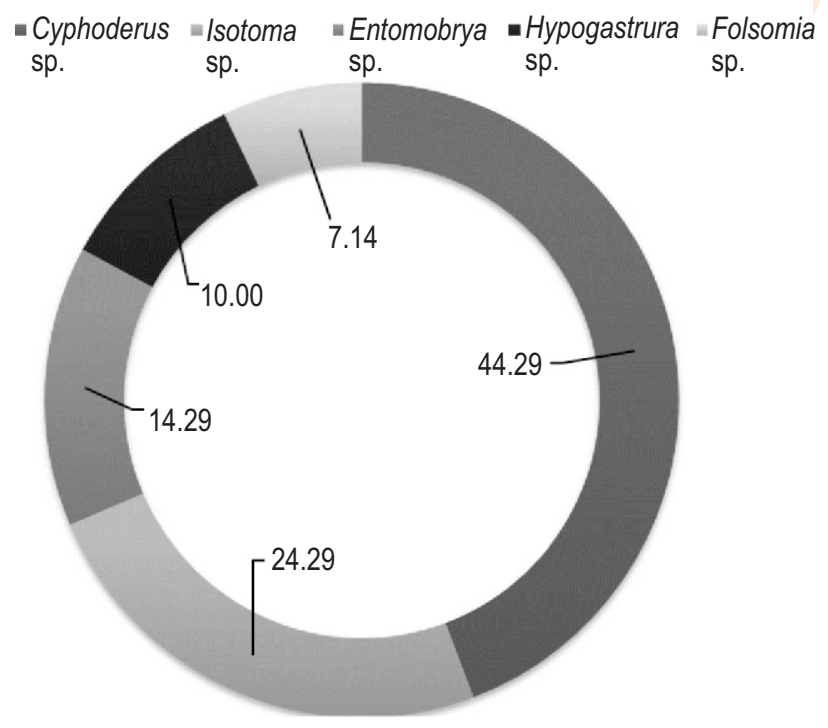

Fig. 1 : Relative abundance of collembolans (\%) in fallow land ecosystem during 2015-16.
During the study period, individuals of above mentioned species were finely distributed which resulted in higher species diversity during all the seasons in fallow land ecosystem. Shannon-Wiener Index values were higher $\left(H^{\prime}=1.48\right)$ in summer indicating relatively stable habitats as compared to autumn $\left(H^{\prime}=1.43\right)$, spring $\left(H^{\prime}=1.40\right)$ and winter $\left(H^{\prime}=1.39\right)$ (Table 2). Species richness calculated through Simpson Diversity Index was recorded to be high during all the seasons and the values ranged between $0.72-0.86$. Individuals of recorded species were also found to be equally distributed during all the seasons as the evenness values registered were closer to 1 ( $E=0.83-0.92$ ). Seasonal increasing trend of collembolan diversity from spring to summer and autumn and then decreased rapidly during winter has been reported earlier (Wiwatwitaya and Takeda, 2005; Muturi et al., 2009; Paul et al., 2011). The increased rate of litter and organic matter decomposition due to raised soil moisture and temperature during summer accelerated the release of carbon in soil, which influenced higher diversity of collembolans as compared to other seasons (Liu et al., 2019). The increase in the abundance of soil dwelling collembolans due to short term heat of soil has also been reported earlier by Holmstrup et al. (2018).

Assessment of season wise density of collembola revealed maximum density ( 266.36 nos. sq $\mathrm{m}^{-1}$ ) during summer, followed by autumn (167.27 nos. sq $\left.\mathrm{m}^{-1}\right)$ and spring (126.36 nos. $\mathrm{sq} \mathrm{m}^{-1}$ ) whereas minimum was recorded during winter season (61.82 nos. sq $\mathrm{m}^{-1}$ ) (Table 2). Month wise fluctuation of collembolan density (nos. sq $\mathrm{m}^{-1}$ ) registered maximum population during the month of August (320.45) followed by July (248.48) and June (212.12) (Fig. 2). The minimum population was registered during February (39.09 sq $\left.\mathrm{m}^{-1}\right)$. These results confirm the findings of Mandal and Suman (2014) who observed the maximum population of collembolans during July which coincided with the maximum proportion of soil moisture and organic carbon content and thereby resulted in acceleration of organic matter decomposition process. The present findings corroborate with the findings of Saikia (2016) who reported maximum population during August (2989.81 sq m${ }^{-1}$ ) and minimum during April (525.21

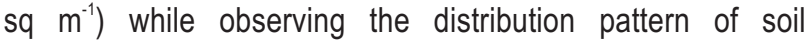
microarthropods in the forest, agricultural and fallow land ecosystem of Assam.

Studies pertaining to correlation of collembolan density and diversity with different physico-chemical properties of fallow land soil (Table 2-4) revealed a strong significant $(P<0.01$ and $\mathrm{P}<0.05)$ positive correlation of collembolan density with soil moisture ( $r=0.902,0.973,0.758$ and 0.925$)$ and organic carbon $(r=0.968,0.934,0.891$ and 0.924$)$ content during spring, summer, autumn and winter, respectively. The diversity of collembolans also exhibited significant $(P<0.01$ and $P<0.05)$ positive correlation with soil moisture $(r=0.821,0.853,0.771$ and 0.862 ) and organic carbon ( $r=0.648,0.951,0.789$ and 0.766 ) during all the seasons, respectively. The collembolan diversity as 
Table 1 : Seasonal fluctuation of collembolan diversity and density in a fallow land ecosystem during 2015-16

\begin{tabular}{llllll}
\hline Season & Shannon Wiener (H') & Simpson Index (D) & $\begin{array}{l}\text { Simpson Index of } \\
\text { Diversity(1-D) }\end{array}$ & Evenness (E) & $\begin{array}{l}\text { Density } \\
\left(\text { Nos. sq } \mathbf{m}^{-1}\right)\end{array}$ \\
\hline Spring & 1.40 & 0.27 & 0.73 & 0.86 & 126.36 \\
Summer & 1.48 & 0.14 & 0.86 & 0.92 & 266.36 \\
Autumn & 1.43 & 0.23 & 0.77 & 0.87 & 167.27 \\
Winter & 1.39 & 0.28 & 0.72 & 0.83 & 61.82 \\
\hline
\end{tabular}

Table 2 : Details of soil physico-chemical properties of fallow land ecosystem during 2015-16

\begin{tabular}{|c|c|c|c|c|c|c|c|c|c|c|}
\hline Season & $\begin{array}{l}\text { Density } \\
\left(\text { No sq } \mathrm{m}^{-1}\right)\end{array}$ & $\begin{array}{l}\text { Diversity } \\
\text { (1-D) }\end{array}$ & $\begin{array}{l}\text { Sand } \\
(\%)\end{array}$ & $\begin{array}{l}\text { Silt } \\
(\%)\end{array}$ & $\begin{array}{l}\text { Clay } \\
(\%)\end{array}$ & $\begin{array}{l}\text { Soil moisture } \\
(\%)\end{array}$ & $\begin{array}{l}\text { Organic } \\
\text { carbon (\%) }\end{array}$ & $\begin{array}{l}\text { SMBC } \\
\left(\mu g^{-1}\right)\end{array}$ & $\mathrm{pH}(1: 2.5)$ & $\begin{array}{l}\text { BD } \\
\left(g c c^{-1}\right)\end{array}$ \\
\hline Spring & 126.36 & 0.77 & 47.6 & 38.5 & 13.9 & 22.15 & 0.61 & 118.90 & 5.4 & 1.36 \\
\hline Summer & 266.36 & 0.73 & 49.1 & 37.6 & 13.3 & 26.25 & 0.67 & 137.72 & 5.4 & 1.39 \\
\hline Autumn & 167.27 & 0.72 & 48.7 & 37.3 & 14.0 & 24.72 & 0.63 & 135.34 & 5.4 & 1.34 \\
\hline Winter & 61.82 & 0.86 & 48.5 & 38.1 & 13.4 & 19.64 & 0.60 & 130.22 & 5.4 & 1.36 \\
\hline
\end{tabular}

Data are mean of 3 samples

Table 3: Correlation of collembolan density with soil physico-chemical properties of fallow land ecosystem

\begin{tabular}{|c|c|c|c|c|c|c|c|c|c|}
\hline Season & & Sand & Silt & Clay & Soil moisture & Organic carbon & SMBC & $\mathrm{pH}$ & BD \\
\hline \multirow[t]{2}{*}{ Spring } & $r$ & 0.125 & 0.226 & 0.355 & $0.902^{*}$ & $0.968^{* *}$ & 0.071 & 0.588 & 0.386 \\
\hline & $p$ & 0.728 & 0.528 & 0.313 & 0.023 & 0.001 & 0.632 & 0.430 & 0.579 \\
\hline \multirow[t]{2}{*}{ Summer } & r & 0.607 & 0.358 & 0.471 & $0.973^{\star *}$ & $0.934^{*}$ & 0.469 & 0.286 & 0.188 \\
\hline & $p$ & 0.062 & 0.308 & 0.168 & 0.011 & 0.031 & 0.128 & 0.558 & 0.995 \\
\hline \multirow[t]{2}{*}{ Autumn } & $r$ & 0.264 & 0.214 & 0.248 & $0.758^{*}$ & $0.891^{*}$ & 0.191 & 0.627 & 0.303 \\
\hline & $p$ & 0.460 & 0.551 & 0.488 & 0.042 & 0.025 & 0.481 & 0.320 & 0.572 \\
\hline \multirow[t]{2}{*}{ Winter } & $r$ & 0.467 & 0.492 & 0.155 & $0.925^{*}$ & $0.924^{*}$ & 0.543 & 0.431 & 0.457 \\
\hline & $p$ & 0.172 & 0.148 & 0.668 & 0.024 & 0.040 & 0.115 & 0.288 & 0.221 \\
\hline
\end{tabular}

${ }^{* *}$ Significant at 1 per cent probability level $p \leq 0.01$; Significant at 5 per cent probability level $p \leq 0.05$

Table 4: Correlation of collembolan diversity with soil physico-chemical properties of fallow land ecosystem

\begin{tabular}{|c|c|c|c|c|c|c|c|c|c|}
\hline Season & & Sand & Silt & Clay & Soil moisture & Organic carbon & SMBC & $\mathrm{pH}$ & BD \\
\hline \multirow[t]{2}{*}{ Spring } & r & 0.247 & 0.049 & 0.668 & $0.821^{*}$ & $0.648^{*}$ & 0.463 & 0.613 & 0.316 \\
\hline & $p$ & 0.490 & 0.891 & 0.340 & 0.022 & 0.028 & 0.218 & 0.480 & 0.648 \\
\hline \multirow[t]{2}{*}{ Summer } & r & 0.573 & 0.065 & 0.431 & $0.853^{*}$ & $0.951^{* *}$ & 0.460 & 0.439 & 0.161 \\
\hline & $p$ & 0.083 & 0.857 & 0.213 & 0.031 & 0.001 & 0.281 & 0.235 & 0.725 \\
\hline \multirow[t]{2}{*}{ Autumn } & r & 0.209 & 0.234 & 0.195 & $0.771^{*}$ & $0.789^{*}$ & 0.192 & 0.565 & 0.213 \\
\hline & $p$ & 0.561 & 0.513 & 0.588 & 0.041 & 0.027 & 0.639 & 0.410 & 0.562 \\
\hline \multirow[t]{2}{*}{ Winter } & r & 0.340 & 0.388 & 0.168 & $0.862^{*}$ & $0.766^{*}$ & 0.611 & 0.346 & 0.497 \\
\hline & $p$ & 0.335 & 0.266 & 0.640 & 0.023 & 0.032 & 0.029 & 0.524 & 0.293 \\
\hline
\end{tabular}

${ }^{* *}$ Significant at 1 per cent probability level $p \leq 0.01$; Significant at 5 per cent probability level $p \leq 0.05$

well as density of fallow land ecosystem although showed positive relationship but was found statistically non-significant with the rest of the studied soil edaphic factors.

The present findings are in accordance with Bhattacharya and Raychoudhuri (1979). Hazra (1978) also reported that the soil moisture acted as pivotal factor for the growth and development of collembolans and strongly correlated with the population of collembolans and their seasonal fluctuations. Numerous edaphic reactions including humification of soil also requires direct involvement of moisture thereby stimulating the growth and development of soil microbial flora and fauna. Significant increase in the collembolan population due to sudden increase of soil organic matter has also been studied earlier (Hazra and Bhattacharyya, 2003; Ghosh and Roy, 2005; Santos et al., 2018), which might be due to decomposition and 


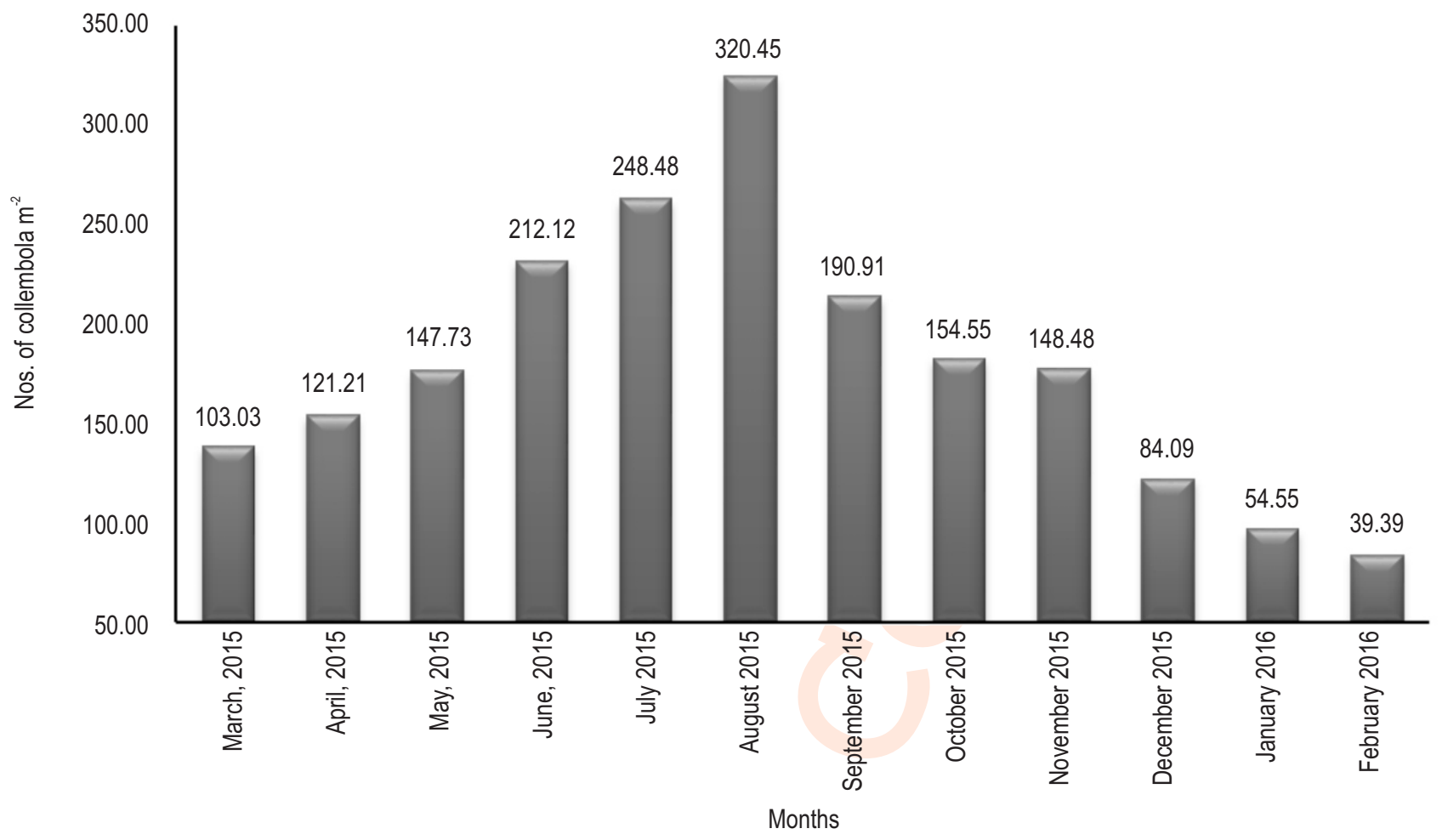

Fig. 2 : Monthly variation of collembolan density (no. $\mathrm{m}^{-2}$ ) in fallow land ecosystems during 2015-16

conversion of available leaf or other litters to organic matter in the top soil which served as a source of sufficient food and provide a healthy ecological niche for many soil arthropods. Devi et al. (2011) also observed a congregation of approximately 85-90 per cent collembolans at the top 0-10 cm layer of soil due to sufficient amount of organic matter and moisture content which favours the growth and development of collembolans. In the present study, bulk density of fallow land ecosystem soil ranged between 1.34$1.39 \mathrm{~g} \mathrm{cc}^{-1}$ with slight acidic $\mathrm{pH}$ (5.4) and found non- significant relationship with the collembolan population which is in conformity with the findings of Ghosh and Roy (2005). Bhagawati et al. (2018) also reported that the $\mathrm{pH}$ and bulk density did not show any significant positive correlation and did not exhibit any direct influence on collembola population.

Although the diversity of collembolans in the North Eastern region of India is very scanty, the aforementioned study provides at least an ideal base for future research on documenting the species diversity of Collembola in different ecosystems to understand the neoteric collembolan fauna of the region.

\section{Acknowledgments}

Authors are grateful to Dr. M. Raghuraman, Department of Entomology and Agricultural Zoology, Institute of Agricultural Sciences, Banaras Hindu University, Varanasi, India for his assistance in identifying the specimen. All other necessary support and essential help provided by Dr. A. S. Baloda, Network
Coordinator, All India Network Project on Soil Arthropod Pests, ICAR, Durgapura, Jaipur (Rajasthan) is duly acknowledged.

\section{References}

Akoijam, R. and B. Bhattacharyya: Standardization of method for soil arthropods extraction by Tullgren funnel. Indian J. Ecol., 39, 153155 (2012).

AOAC: Association of Official Analytical Chemists. $17^{\text {th }}$ Edn., AOAC, Washington DC, USA (2000).

Bartz, M.L.C., A. Pasini and G.G. Brown: Earthworms as soil quality indicators in Brazilian no-tillage systems. Appl. Soil Ecolo., 69, 3948 (2013).

Bhagawati, S., B. Bhattacharyya, S. Bhattacharjee, H. Mishra and B.K. Medhi: Impact of soil physico-chemical properties on the density and diversity of Collembola in Majuli river island, Assam, India. J. Entomol. Zool. Stud., 6, 837-842 (2018).

Bhattacharya, T. and D.N. Raychoudhuri: Monthly variation in the density of soil microarthropods in relation to some climatic and edaphic factors. Ento., 4, 313-318 (1979).

Cassagnau, P.: A Collembola adapted to predation: Cephalotoma grandiceps (Reuter). New Ento. Rev., 2, 5-12 (1972).

Chapman, H.D.: Cation exchange capacity. In: Methods of Soil Chemical Analysis (Eds.: C.A. Black). American. Society of Agronomy, Madison, Wisconsin, USA, pp. 891-901 (1965).

Clarke, K.R. and R.M. Warwick: Changes in marine communities: An approach to statistical analysis and interpretation. $2^{\text {nd }}$ Edn., PRIMERE: Plymouth, UK (2001).

Cortet, J., D. Ronce, N.P. Balaguer, C. Beaufreton, A. Chabert, P. Viaux and J.P.C. Fonseca: Impacts of different agricultural practices on 
the biodiversity of microarthropod communities in arable crop systems. Europ. J. Soil Biol, 38, 239-244 (2002).

Culik, M.P. and D.J. Filho: Diversity and distribution of Collembola (Arthropoda: Hexapoda) of Brazil. Biodiver. Conser., 12, 1119$1143(2003)$

Devi, W.M., T.B. Singh and L.J. Devi: Monthly changes of collembolan population under the gradients of moisture, organic carbon and nitrogen contents in a sub-tropical forest soil, Manipur. J. Experiment. Sci., 2, 10-12 (2011).

Fiera, C.: Biodiversity of Collembola in urban soils and their use as bioindicators for pollution. Brazilian Agric. Res., 44, 868-873 (2009).

Filho, L.C.I.O., O.K. Filho, D. Baretta, C.A.S. Tanaka and J.P. Sousa: Collembola community structure as a tool to assess land use effects on soil quality. Brazilian J. Soil Sci., 40, 1-18 (2016).

Ghosh, T.C. and S. Roy: Collembolan community in a tea garden soils of Darjeeling Himalayas. Environ. Ecol., 23, 412-417 (2005).

Guru, B.C. and A.K. Mohanty: Species composition, distribution and seasonal variation of Collembola in two agroecosystems of Bhubaneswar, India. In: Advances in Ecology and Environmental Sciences (Eds.: B.C. Guru, B.K. Senapati, N. Behera and P.C. Mishra). Ashish Publishing House, New Delhi, India, pp. 100-103 (1995).

Hazra, A.K. and B. Bhattacharyya: Studies of Collembola from agricultural fields and waste disposal sites of West Bengal with special reference to their microbial association. Rec. Zool. Survey of India, 214, 1-199 (2003).

Hazra, A.K.: Ecology of Collembola in a deciduous forest floor of Birbhum district, West Bengal in relation to soil moisture. Ori. Insects, 12, 265-274 (1978).

Holmstrup, M., B.K. Ehlers, S. Slotsbo, K. llieva-Makulec, B.D. Sigurdsson, N.I.W. Leblans, J. Ellers and M.P. Berg: Functional diversity of Collembola is reduced in soils subjected to short- term, but not long- term, geothermal warming. Functional Ecol., 32, 1304-1316 (2018).

Hopkin, S.P.: Biology of the Springtails (Insecta: Collembola). $1^{\text {st }}$ Edn., Oxford University Press, Oxford, UK (1997).

Jackson, M.L.: Soil Chemical Analysis. $1^{\text {st }}$ Edn., Prentice Hall of India. Pvt. Ltd., New Delhi, India (1973).

Larink, O.: Springtails and mites: Important knots in the food web of soils. In: Fauna in Soil Ecosystems: Recycling Processes, Nutrient Fluxes, and Agricultural Production (Eds.: G. Benckiser). Marcel Dekker, New York., pp. 225-264 (1997).

Leinster, T. and C.A. Cobbold: Measuring diversity: The importance of species similarity. Ecology, 93, 477-489 (2012).

Liu, Y., L. Wang, R. He, Y. Chen, Z. Xu, B. Tan, L. Zhang, J. Xiao, P. Zhu, L. Chen, L. Guo and J. Zhang: Higher soil fauna abundance accelerates litter carbon release across an alpine forest-tundra ecotone. Science Reports, 9, 1-12 (2019).

Mandal, G.P. and K.K. Suman: Studies on diversity and distribution of soil microarthropods fauna with special reference to Collembola in Sajnekhali Wild Life Sanctuary, South 24 PGS, West Bengal. Rec. Zool. Survey India, 114, 623-636 (2014).

Muturi, J.J., J.P. Mbugi, J.M. Mueke, J. Lagerlóf, J.K. Mungatu, G. Nyamasyo and M. Gikungu: Collembola density and diversity along a gradient of land- use types in Embu district, Eastern Kenya. Trop. Subtrop. Agroecosys, 11, 361-369 (2009).

Paul, D., A. Nongmaithem and L.K. Jha: Collembolan density and diversity in a forest and an agroecosystem. Open J. Soil Sci., 1, 5460 (2011).

Saikia, A.: Occurrence of soil arthropods in different ecosystems of Assam. J. Entomol. Res., 40, 59-63 (2016).

Santeshwari, M. Raghuraman and J. Singh: The preliminary identification characters of some collembola from Varanasi region of Uttar Pradesh, India. Bioscan, 8, 271-280 (2013).

Santos, M.A.B., L.C.I.O. Filho, P.N. Pompeo, D.C. Ortiz, A.L. Mafra, O.K. Filho and D. Baretta: Morphological diversity of springtails in land use systems. Brazilian J. Soil Sci. 42, 1-19 (2018).

Simpson, E.H.: Measurement of diversity. Nature, 163, 688-691(1949).

Singh, J., S.V. Mahajan and R.K. Singh: Sampling, extraction and precision regarding some statistical studies for population ecology of soil mesofauna. Bull. Entomol. Res., 19, 130-145 (1978).

Sousa, J.P., M.M. Da Gama, C. Pinto, A. Keating, F. Calhoa, M. Lemos, C. Castro, T. Luz, P. Leitao and S. Dias: Effects of land-use on Collembola diversity patterns in the Mediterranean landscape. Pedobiol., 48, 609-622 (2004).

Sousa, J.P., T. Bolger, M. Manuela da Gama, T. Lukkari, J. Ponge, C. Simon, G. Traser, A.J. Vanbergen, A. Brennan, F. Dubs, E. Ivitis, A. Keating, S. Stofer and A.D. Watt: Changes in collembola richness and diversity along a gradient of land-use intensity: A pan European study. Pedobiol., 50, 147-156 (2006).

Stork, N.E. and P. Eggleton: Invertebrates as indicators of soil quality. American J. Alter. Agric. 7, 38-47 (1992).

Vance, E.D., P.C. Brookes and D.S. Jenkinson: An extraction method for measuring soil microbial biomass carbon. Soil Bio. Biochem., 19, 703-707 (1987).

Van-Straalen, N.M.: Community structure of soil arthropods as a bioindicator of soil health. In: Biological Indicators of Soil Health (Eds.: C.E. Pankhurst, B. Doube and V.V.S.R. Gupta). CAB International, Wallingford, UK., pp. 235-264 (1997).

Walkey, A. and I.A. Black: An examination of Degtjareff method for determining soil organic matter, and a proposed modification of the chromic acid titration method. Soil Sci., 37, 29-38 (1934).

Wiwatwitaya, D. and H. Takeda: Seasonal changes in soil arthropod abundance in the dry evergreen forest of north-east Thailand, with special reference to collembolan communities. Ecol. Res., 20, 5970 (2005).

Zeppelini, D., B.C. Bellini, A.J. Creao-Duarte and M.I.M. Hernández: Collembola as bioindicators of restoration in mined sand dunes of North eastern Brazil. Biodiver. Conser., 18, 1161-1170 (2009). 